УДК 009

\title{
Sensual and Intuitive Reflexion of Culture in Russian Symbolism of the End of the XIX - the Beginning of the XX Century
}

\author{
Oleg Yu. Astakhov* \\ Kemerovo State Institute of Culture \\ 17 Voroshilova Str., Kemerovo, 650029, Russia
}

Received 11.04.2016, received in revised form 26.05.2016, accepted 19.07.2016

The study considers ideas of Russian symbolism of the end of the XIX the beginning of the XX century connected with discovering new possibilities for world realizing in culture. Moreover the study focuses attention on the theoretical works of $V$. Ia. Briusov devoted to art reasoning. Briusov V. Ia. examines art within overcoming rational attitude to the world through releasing sensual intuition as a way for implementing life in the act of free creativity.

Keywords: Russian symbolism, sensual and intuitive reflexivity, creativity, world attitude.

DOI: 10.17516/1997-1370-2016-9-8-1888-1895.

Research area: culture studies.

\section{Introduction}

Most of researchers note that emphasized reflexivity of creative searches in Russia of the end XIX - the beginning of the XX century, the period called as "Silver age" is the invariable art characteristic for a turn of centuries. These specifics of sensual attitude in art culture of Russia of the end of XIX - the beginning of the XX century are considered in the works of such researches as I. V. Koretskaia, L.G. Andreev, L.V. Usenko, I. I. Ioffe, M B. Alpatov, Z. G. Mints and etc. Many modern researchers characterize this feature as a reaction to epoch-making crisis tendencies in Russian culture of the beginning of the XX century (N. A. Hrenov, I.V. Kondakov,
T.F. Kuznetsova, N. Bogomolov, Z. Zhukotskaia and etc.). Besides, the internal features characterizing art reflexivity of a turn of centuries are defined in the works of D.E. Maximov, V. E. Kovskii, V. F. Asmus, S. I. Gindin, V. N. Orlov, E. P. Bernshtein, L. E. Liapina, L. Ia. Ginzburg, A. B. Fedorov, K. M. Chernyi and etc. Moreover these ideas are represented in the works of the poets of the end of XIX the beginning of the $\mathrm{XX}$ century such as K. Bal'mont, V. Briusov, I. Annenskii, M. Voloshin, V. Ivanov, A. Belyi and etc. and these are the undoubted evidence of a special world attitude focused on searching valuable reference points not only in art, but also in culture

(c) Siberian Federal University. All rights reserved

* Corresponding author E-mail address: astahov_oleg@mail.ru 
in general which aren't excluding plurality of their meanings and values.

The aspiration to reconsider past values, to develop essentially new, unclassical approach to culture brought to life many acute contradictions creating the internal tension of Russian cultural Renaissance. Not incidentally N. Berdiaev in his work "Self-knowledge" noted that Russian cultural Renaissance represented an era of emerging new souls, new sensitivity (Berdiaev, 1999, 412). Updating the sensual attitude to the world defined activity of creative searches of a turn of centuries in the solution of the questions for self-determination necessary in connection with establishing new valuable reference points of culture (Guliuk, 2007).

\section{Theoretical framework. Symbolism as a new form of world attitude}

The aspiration to reconsider past values, to develop essentially new, unclassical approach to culture brought many acute contradictions creating the internal tension for an era of Russian cultural Renaissance to life. The reaction for releasing spiritual culture was the symbolism opened new ways for cultural development. Arisen in the 1880th years as a direction of French literature (P. Verlaine, A. Rimbaud, S. Mallarmé) symbolism found adherents in many European countries, thus influenced on art in general, having become the many-sided art and philosophical movement, dictating to its supporters not only certain creative principles, but also lifestyle that, certainly, further couldn't but affect the nature of culture. In the 1890th years a powerful stream of the first Russian symbolism wave joined this all-European direction: N. M Minskii's philosophical and publicistic manifestos "By the light of conscience" (1890), D. S. Merezhkovskii "About the reasons of decline and about new direction of modern Russian literature" (1893) are published in Russia, V. Ia. Briusov's poetic collection "Russian Symbolists" (1894-1895) is appeared, the works of F. Sologub, Z. Gippius, K. D. Bal'mont are issued, the translation activity of the Russian poets acquainting readers with new trends in European literature is developed. The Russian symbolism was fated to endure the highest creative take-off in the 1900th years that is connected with the introduction in literature of a new group of poets: A. Belyi, A. Blok, V. Ivanov, In. Annenskii, S. Solov'ev, Ellis (L. L. Kobylinskii), M. Voloshin, Iu. Baltrushaitis.

Implementing new form of world attitude as a way for updating symbolism is presented in early V. Ia. Briusov's works, one of the founders of a new art. In the 1890th years the poet was famous for his rather scandalous character, than literary, his works caused ambiguous reaction. V. Ia. Briusov really gave his opponents the serious grounds for claims as his works weren't addressed to any certain reader's taste, and he couldn't be carried to any concrete literary direction. As V. E. Kovskii noted, in the 1890th years of the XIX century, V. Ia. Briusov in the opinion of criticism inadmissibly broke traditions. "At that time, - A. Belyi remembered V. Ia. Bryusov, he was lonely, having against him all Russian literature and all Russian criticism... He went, surrounded with words of sarcasm and hatred" (Kovskii, 1990, 24).

Symbolism from the first days of its existence aspired to develop the theoretical program, to be created in esthetic and even a philosophical direction. The cornerstone of this theory was the purpose of art and poetry, their public function, and a high aspiration of a poet. Originally V. Ia. Briusov headed for the theory aimed to present symbolism as an esthetic phenomenon, and tried to bring out art "autonomy" in its relations with public reality and different types of ideology. Young V. Ia. Briusov believed that the main task of a new art going to change realistic 
creativity with its aspiration to the objective world is the exposure of the sensual beginning. He wrote: "There are two kinds of poetry. One is content with the image of that it is possible to comprehend with the help of mind, expression of the feelings available to clear consciousness. Its force in transferring visible and external, in brightness of descriptions and the accuracy of definitions...

The poetry of other kind incessantly tries from visible and external to the super sensual. It is attracted by dark and mysterious depths of human spirit, those vague feelings which are endured somewhere outside consciousness. Its area is pure lyrics. The poet feels himself below his creation, as if he has to be sent to the power of an intuition. Of course, it doesn't mean that such works were incoherent; at the seeming disorder they keep spiritual integrity; elusiveness of moods doesn't stir deep deliberation of separate expressions" (Briusov, 1990, 50). All aforesaid is peculiar not only for creativity of Vl. Solov'ev, but also for V. Ia. Briusov. In the letter to "the charming stranger" ("Answer") V. Ia. Briusov tries to answer the question "What is essence of symbolism?" "The poet reflects a number of images which yet haven't developed in a full picture, connecting them in a single whole, or putting them in scenes and dialogues, or simply listing them one by one. The communication given to these images, always more or less casual so it is necessary to consider them as milestones of an invisible way opened for the reader's imagination. Therefore it is possible to call symbolism as also you inconsistently do, - "poetry of hints"... So, at new romantic school every image, each thought is in the extreme conclusions. Symbolism, on the contrary, takes their first gleam, a rudiment, it isn't defined sharply with certain outlines, and, thus, it doesn't differ from other literary schools, than they among themselves. Try to track yourself when you dream, and then express the same in the words: you receive a prototype of symbolical work and work in the spirit of the dominating school.

It results from this that not only the poetsymbolist, but also his reader should have sensitive soul and in general has delicate insight. It is necessary to get a grasp of symbolical work; the imagination has to recreate only the planned thought of the author" (Briusov, 1990, 43). The author focuses attention on a reflexive perception of the world; developing "the theory of hints" allows making an active imagination of the recipient that is necessary at updating poetry and its language connected with changing reality and an interior. Enhancing reader's perception is taken into consideration already at a stage of creating a work of art and becomes as if a structural element of the text, it is the constructive sign uniting, according to V. Ia. Briusov, all kinds of "a new direction" and justifying named the last "poetry of hints". And in this way the position of the author becomes especially close to K. Bal'mont's ideas regarding the modern art presented in the article "Simple words about symbolical poetry" published in the collection "Mountain tops" (1904). In this work the dialogue with the reader demanding updating the author's word is set ascertaining from the very beginning. Describing a daily situation of supervision from the window over the movement of crowd passing, the author offers such inversion when the interlocutor has to see hidden life behind obvious appearance, "and all these ghosts thinking that they live, will appear before you only as moving fabrics, as creations of your own dream" (Bal'mont, 2001, 52). Discovery of the world is represented to $\mathrm{K}$. Bal'mont as discovery of the dream operated by subjective thought therefore it becomes independently created phantasmagoria. Thus, expressing the inner world containing the ideal pan-esthetic values capable to carry away the reader with the changeable values and with the 
feeling of a hint, innuendoes and etc. becomes the essential characteristic of symbolism for the poet (Astakhov, 2015).

In 1904 V. Ia. Briusov's article "Keys of secrets" was published in the first issue of the journal "Vesy", where the main theoretical views of the author on the principles of symbolism as the modern art were distinctly formulated. In the structure of the published manifesto is possible to allocate some parts characterizing various stages of the human thought relation to art according to V. Ia. Briusov's remark. The author connected the first level of his understanding with the desire to find any application in life, "so the theories of useful art are arose, it is the most primitive stage in the relations of human thought to art" (Briusov, 1990, 89). Referring to the Reskin's theory of art with his installation on fidelity to the Nature, the author notes, modern ideas of "useful art" keep the supporters. But because of knowledge and science, according to V. Ia. Briusov, it is impossible to see in art only reflection of life, "there is no art which would repeat reality" (Briusov, 1990, 91). However as the only argument justifying realization of useful art, V. Ia. Bryusov adopts the statement that it can serve for communication among individuals (Briusov, 1990, 92).

The similar exception was not casual supervision of the author, in 1894 in the preface to the collection "Russian Symbolists", V. Ia. Briusov formulates the key thesis defined further nature of his understanding a new art: "The symbolism purpose is as if to hypnotize the reader, to cause in him familiar mood with a number of the compared images" (Briusov, 1990, 35). Thus, the attention is actualized on communication in which the dominant position is held by a sensual and reflexive position of the author though at the same time strengthening the reader's perception become significant, taken into consideration already at a stage of creating work and becoming as if a structural element of this work. (Astakhov, 2004). Its implementation promoted the appeal of the poet to incomplete definiteness, or indefiniteness of various semantic aspects. According to S. Mallarmé, who opposites "un principe de vers" the poetic speech as hinting to ordinary and reporting speech, and who learns how to use dematerialization for the word that it realizes the idea, V. Ia. Bryusov defends art of hints and approves necessity of a sparseness, illusoriness of figurative fabric.

In V. Ia. Briusov's work "Keys of secrets" the following stage of the human thought attitude to art is exposed to criticism, characterizing by isolation from life, the isolation in itself, excluding possibility of the relation to any mercenary purposes. So the theories of "pure art" are arose (Briusov, 1990, 93). In this case an appeal of the artist to Beauty becomes creativity dominant. Whatever significant Aristotle's ideas were and his late follower Bualo about necessity to keep the rules of harmony, V. Ia. Briusov notes: "Art for aimless Beauty (from the capital letter) is dead art" (Briusov, 1990, 96). Therefore life updating generates, firstly, the possibility to refuse understanding beauty from typicalness that generates installation on reflexivity, secondly, the possibility to refuse strict forms in favor of mobility and variability of art that also opens the road to sensual moods and experiences. In this regard N. E. Musinova notes that "V. Briusov consciously displaces esthetic values towards destructive art" (Musinova, 2010, 60). Modern poets, according to V. Ia. Briusov, have to turn a look in themselves and express the experiences which are "the only reality" out of the attitude towards steady meanings and values. Therefore the poet has to reflect safely the experiences with all the doubtful and dark motives.

"The artist can't do bigger than to open his soul for another," - V. Ia. Briusov writes in his work "About art", published in 1899 (Briusov, 1987, 41). "Poetry hasn't other contents except 
soul of the person," - the author notes in the work "Iv. A. Bunin. New poems", published in 1902 (Briusov, 1990, 70). These statements about necessity for releasing the reflexivity in the act of free creativity can be continued addressing to other works of V. Ia. Briusov, as understanding art for the author is essential only in the attitude towards feelings of the person. Therefore D.E. Maximov, representing views of symbolists, noted that for V. Ia. Briusov the psychological and aesthetic feeling of spiritual and cultural values is very considerable (Maximov, 1986, 41).

Art focus on reflexivity makes impossible the appeal to science in defining significant characteristics of creativity. This is the next key statement of the V. Ia. Briusov's manifesto "Keys of secrets" characterizing the human thought attitude to art within its scientific judgment: "The science has no claims to get into essence of things. The science knows only a ratio of the phenomena; it is only able to compare them and to match. The science can't consider anything without the attitude towards another. The statements of science are supervision of the things and phenomena ratios" (Briusov, 1990, 96). It is impossible to explain esthetic disorders through physiology or psychology; in this case the conducted analogies are doubtful. The genetic analysis of art carried out within a scientific evolutionism which led to the discovery made still by Schiller and supported by Spencer, that game is the creativity basis, also doesn't maintain criticism. "If any art is game, so why isn't any game art?" - V. Ia. Briusov asks a question (Briusov, 1990, 99). Thus just as definitions of art essence as "useful" and "pure" theories are too narrow, scientific definition of art is too wide already because even such question of one-dimensional phenomena essence in science can't exist. As E. S. Tailakova notes, the world for V. Ia. BrIusov is learned, but its complexity consists in lack of simultaneous immersion in himself and in out of the world. In this conceptual contradiction also there is a V. Ia. Briusov's axiom of true plurality. Each truth is absolute, complete, comprehended and at the same time opposed to other truth (Tailakova, 2012). More developed content of these ideas V. Ia. Briusov gives in his work "Truth. The beginnings and hints", in which the free will is considered as the predominating knowledge condition, opening, finally the importance of a self-reflection. (Briusov, 1975). Thus, focusing attention on "I", according to D.E. Maximov's remark, "Briusov didn’t seek for coordinating contradictory truth and admitted the fact of its coexistence in consciousness of the personality as the sign of wealth" (Maximov, 1986, 40).

The criticism of the listed stages for the human thought attitude to art leads V.Ia. Briusov to idea about the only method capable to open the maintenance of life, - intuitions, inspired guessing; and this differentiate art from science which is capable to bring only an order in chaos of false representations, doing possible recognition, but not knowledge. Addressing to unclassical philosophy of A. Shopengaur, the author formulates the truth opening to him: "Art is comprehension of the world in other, but not rational ways. Art is that in other spheres we call revelation. Art creation is the half-opened doors into Eternity" (Briusov, 1990, 100). Art becomes the act of the world knowledge out of rational and logical forms. And symbolism in the author's ideas, as I. V. Chindin notes, has to provide people the highest and universal way of knowledge turned not to an external cover of the phenomena, and directly to its essence (Chindin, 2010).

In this regard for V. Ia. Briusov there are valuable philosophical ideas of A. Shopengaur about intuitively formed and endured motivations of the person which are the cornerstone of any person's knowledge. According to the German philosopher, 
the main thing is not the knowledge of the phenomena, but penetration into essence, into the world of "transcendental objects" that can be comprehended only through intuition. Of course, "transcendental object" isn't learned, but it can be recognized, and this recognition is realized through art, which should be considered as a way for overcoming action of the World will. Thoughts about this irrational will understood as unrestrained volition, desire without the beginning and the end, out of any goal-setting hold the central position in his philosophy. Being a basis and essence of the world, the World will is uniform, identical to itself, invariable, free, stays regardless time and space, doesn't submit to laws of causality. "... the Will, - the philosopher writes, - is the core, a kernel of all private, as well as whole; it is shown in each blindly operating force of nature, but it is shown in the considered activity of the person: great distinction between them concerns only extent of manifestation, but not essence of that is shown" (Schopenhauer, 1992, 107.) - The philosopher proves the pessimistic thoughts of infinite suffering of the person action due to blind and unreasonable will. But is it possible to overcome? A. Schopenhauer declares necessity of discharge from himself and even destructions of that can break action of the World will. And the first steps of self-destruction of the will is the esthetic contemplation which is realized in art which the philosopher considers through Kant's tradition as action free from any interest in any utilitarian significant results and independent of egoistical feelings. Thus the philosopher takes a serious step in understanding further release of creativity from the concrete aims depending on the World will. His oblivion in the enlightenment moments, as it is paradoxical, at the same time it means our disposal, and the will from itself as life carriers in its rational contents.

Briusov V. Ia., developing these ideas, notes: "The primordial problem of art also consists in imprinting these moments of enlightenment, inspiration. Art begins in that moment when the poet tries to realize dark and secret feelings. Where there is no such understanding - there is no art creativity. Where there is no such secret in feeling - there is no art. If the person thinks that everything in the world is simple, clear and conceivable, he can't be the poet" (Briusov, 1990, 101). Thus, mission of the poet is to open more perfect ways of understanding the world connected with the appeal to the subjective intuitive feeling capable to overcome limits of cognizable. As Z. G. Mints fairly notes, characterizing features for dynamics of symbolist aspirations, intuitionalism, denial of logical thinking, the scientific analysis these are the features of symbolist world outlook, however not identical for refusing aspiration to comprehend "secrets" and "riddles" of life. It is rather about to identify any knowledge with art (Mints, 2004, 59).

\section{Conclusion}

Considering symbolism as a way for intuitive understanding the world, V. Ia. Briusov points the dominating reflexivity of the poet, capable by efforts of an intuitive feeling to come nearer to secrets of the universe. Having declared himself in the middle of the 1890th years as the individualistic declaration of self-sufficient "I", further the author addresses to possibility for overcoming limits of subjectivity due to aspiration to capture immense, to be open for the whole world. Expansion of this statement is read in the author's works as implementing possibility for finding true freedom. Thus, V. Ia. Briusov's view for awareness of the importance of the reflexive bases in comprehension of the phenomena 
essence defined the maintenance of symbolism as art opening possibilities for overcoming the rational attitude to the world through releasing intuitionalism as a way of realizing the life in the act of free creativity. Thus, as N. G. Matveevskaia notes, subjectivity is connected with the polyphony opening possibilities for overcoming spiritual dissociation of an era (Matveevskaia, 2009).Such conclusions prepared further way for emerging ideas of "younger" symbolists on implementing cultural and creative ideas focused already not so much on knowledge, but on self-affirmation of will and action in forming the culture opening opportunities for developing new world outlook.

\section{References}

Astakhov, O. Iu. (2015) Defining symbolism as a form of subjective attitude in the early works of K. Balmont. News of Ural Federal University. Series 1: Problems of education, science and culture, 138(2). 148-153.

Astakhov, O. Iu. Estetika impressionizma v poezii russkikh simvolistov (V.Ia. Briusob, K.D. Bal'mont, I.F. Annenskii) [Aesthetics of impressionism in poetry of Russian symbolists (V.Ia. Briusob, K.D. Bal'mont, I.F. Annenskii)]. Kemerovo. 2004.

Bal'mont, K. Elementarnye slova o simvolicheskoi poezii [Simple words about symbolical poetry]. Literaturnye manifesty: Ot simvolizma do "Oktiabria" [Literary manifestos: From symbolism to "October"]. Moscow, 2001, pp. 52-61

Berdiaev, N. A. Samopoznanie [Self-knowledge]. Moscow. 1999.

Briusov, V. Ia. Sobranie sochinenii v 7 t. [Collected works in 7 vol.]. Moscow, 1975. Vol. VI, $648 \mathrm{p}$.

Briusov, V. Ia. Sredi stikhov 1894-1924. [Among poems 1894-1924]. Moscow. 1990.

Briusov, V. Ia. Sochineniia: V $2 t$. [Works in 2 volumes]. Moscow.1987.

Guliuk, L. A. (2007) The crisis is a cause of the myth in the transitional epoch of the silver century. Scientific sheets of Belgorod state university. 33(2). 180-186

Kovskii, V. E. Realisty i romantiki [Realists and romantics]. Moscow. 1990.

Maksimov, D. E. Russkie poety nachala veka: Ocherki [Russian poets of the beginning of the century: Sketches]. Leningrad. 1986.

Matveevskaya, N. G. (2009) Antinomy of «borders » and «boundless» in Briusov's lyrics (on the structure of the image of a lyrical subject) Bulletin of Nizhegorodski university of N.I. Lobachevskii. 1. 255-259.

Mints, Z. G. O nekotorykh "neomifologicheskikh" tekstakh v tvorchestve russkikh simvolistov [About some "neomithological" texts in the works of Russian symbolists] // Blok i russkii simvolism: Izbrannye Trudy: $V 3 \mathrm{kn}$. [Blok and Russian symbolism: The chosen works in three books]. Saint Petersburg. 2004. Book 3: Poetics of Russian symbolism. P. 59 - 96.

Musinova, N. E. (2010) V. Ya. Briusov in the Quest for new Artistic Forms News of Saratov university. Series Philology. Journalism. 10 (3). 57-63

Tailakova, E. S. (2012) Philosophical principles of V. Ia. Briusov Actual problems of humanities and natural sciences. 9. 193-197.

Chindin, I. V. (2010) Philosophical aspects of V. Ia. Briusov's creative evolution Bulletin of Viatsk state university. 4(2). 90-96.

Schopenhauer, A. Sobranie sochinenii v 6 t. [Collected works: in 6 v.]., Moscow 1992, v.1. 


\title{
Чувственно-интуитивная рефлексия культуры \\ в русском символизме \\ конца XIX - начала XX века
}

O.Ю. Астахов

Кемеровский государственный институт культуры Россия, 650029, Кемерово, ул. Ворошилова, 17

\begin{abstract}
Рассматриваются идеи русского символизма кониа ХІХ-начала ХХ века, связанные с открытием новых возможностей миропонимания в культуре. Внимание акцентируется на теоретических работах В. Я. Брюсова, посвященных рассуждениям об искусстве, преодолевающем рациональное отношения к миру через освобождение чувственной интуиции как способа реализачии самой жизни в акте свободного творчества.

Ключевые слова: русский символизм, чувственно-интуитивная рефлексия, творчество, мироощущение.
\end{abstract}

Научная специальность: 24.00.00 - культурология. 